\title{
Collapsed Buildings: Whose Fault - Clients, Engineers, Architects, Quantity Surveyors, Town Planners or Contractors?
}

\author{
Okorie V. N. ${ }^{1, *}$ and Omoregie M. J. ${ }^{2}$ \\ ${ }^{1,2}$ Department of Quantity Surveying, Faculty of Environmental Sciences, University of Benin, Benin City, Edo \\ State, Nigeria \\ Corresponding Author:*v.okorie@yahoo.com
}

\begin{abstract}
Buildings collapses in the Nigerian major urban cites continues to engender an excessive number of fatalities, injuries and property damage. This study investigates whose fault, the clients, engineers, architects, quantity surveyors, town planner or contractors in the cause of incessant collapse of building in Lagos State. Two research approaches were employed - quantitative and interview protocol. The findings revealed that greed and engagement of quacks by building clients, lack of commitment by top management of contracting firms, bribery and corruption among town planning officers ranked highest. Thus, achieving sustainable environment, liveable, viable, quality buildings, and better performance deserves collective responsibilities of key participants in building construction delivery chain, particularly during the early planning and design stage. The study therefore, recommends that the key stakeholders should have a rethink and attitudinal change towards their roles and responsibilities in all matters concerning building construction process and save the country from wanton destruction of precious life and property resulting from incessant buildings collapses in our major urban cities.
\end{abstract}

Keywords: Building collapse, Collective responsibilities, Stakeholders, Nigeria

\subsection{Introduction}

The construction industry remains a high risk business, accounting for one of the major causes of fatalities in Lagos State. Research conducted by Dimuna (2010) to investigate the death rate resulting from building collapses in the Nigeria major urban cities between 2000 and 2010 indicated that Lagos had the highest behind Port Harcourt and Abuja. Thus, the roles of key participants and government agencies involved in building construction should be effectively investigated to avert incessant building collapses.

Over the years, residents of Lagos State have witnessed consistent building collapse leading to fatalities, litigation, regulatory actions, pains, injuries, delayed schedules, tarnished image of contractors, high costs of medical cares and loss of property, etc. On September 12, 2014, six-storey building guest-house belonging to the Synagogue Church of all Nations' at Ikotu in Lagos State collapsed and killed over 117 people mainly of other nationals who came to seek the face of God, and the report also had it that over 350 people were injured (Guardian, 2016). The death of 117 other nationals made headline news in both international and local newspapers. Again, on March 8, 2016, a five-storey building still under construction at Horizon 1, Lekki Gardens, Ikate in Lagos State collapsed killing 35 people and over 20 injured (Guardian,2016). This reckless destruction of precious lives is highly unacceptable.

Statistics show that in every one month 3-5 buildings collapse in the Metropolitan City of Lagos alone. This is translated to 35-60 buildings in a year. Thus, one may be prompted to ask the following questions. Who designed the buildings? Did the buildings receive approval plan from the appropriate authority? What are the competencies of the contractors employed to carry out the construction work 
and supervision? Answers to these pertinent questions and more will reveal whose fault for buildings collapses in Nigeria major urban cities.

Natural occurrences outside the control of man such as earthquakes and tremors, landslide, flooding, high wind velocities like hurricane, etc. have contributed to building failures or total collapses in many parts of the World. For instance, Germany, USA, Chain, Russia, Spain etc. have suffered from these natural phenomena. However, in Nigeria the case is different as there are no records yet indicating that these natural phenomena have resulted in building collapses.

Building collapses could probably be attributed largely to design or construction related factors and the roles of clients and their appointed agents in not ensuring quality (Iyagba, 2009). It has been noted that absence of planning approval and improper soil investigation contribute to unsafe structure or failure (Iyagba, 2002). However, a critical review of the causes of building collapse points to failure of responsibilities and unethical behaviours of the key project stakeholders. Iyagba (2009) stated that reducing the spate of buildings collapse in Nigeria major urban cities requires transparent, commitment and ethical behaviour among the key project participants. For instance, the clients as the building owner and financier have responsibilities and duties under the common law and regulations to ensure that their buildings are constructed in a safe manner. However, instances have shown that clients, particularly private clients engage the services of quacks and sometimes abandon the original approved plan due to greed.

The endemic collapse of buildings in Nigeria major urban Cities, particularly Lagos State is worrisome to stakeholders, government and individuals. The colossal economic losses associated with these ugly events in terms of loss in human lives, property damage is highly unacceptable. Thus, there is a need for collective responsibilities of the key stakeholders in all stages of building delivering chain in order to reduce the spates of buildings collapses in Nigeria.

Previous research work focused on causes of buildings collapse in Nigeria such as: the menace of sick buildings (Iyagba, 2009), building disaster and failure (Fadamiro, 2002); incessant incident of building collapse in Nigeria (Dimuna, 2010), and building collapse and safety concern in Lagos (Guardian Newspaper, 2016). Set against these previous studies, this study seeks to fill in the gap by investigating whose fault among the clients, engineers, architects, quantity surveyors, town planner, or contractors to buildings collapses in Nigeria major urban cities. Examining duties and responsibilities of these key building participants at the early stage of building conception and designing will help in distributing liability for occurrence.

\subsection{Literature review}

\subsubsection{Responsibilities and ethical behaviours of key stakeholders}

Globally, causes of building collapses have been attributed to either natural disaster or failure of responsibilities and unethical behaviours of the key stakeholders. Nevertheless, in Nigeria studies have shown that the $99 \%$ of buildings collapses in the major urban cities are man-made that is failure of responsibilities and unethical behaviours of clients, engineers, architects, quantity surveyors, town planner and contractors. However, building failure or collapse can occur during construction and during use (Dimuna, 2010)). Thus, any type of failure or collapse in building that is not resulting from natural phenomena is traceable to failure of responsibilities and unethical behaviours of key stakeholders.

Arguably, achieving sustainable environment, liveable, viable, quality buildings, and better performance in the Nigerian building industry could be achieved through commitment and behavioural change of the key participants in the industry (Iyagba, 2009; Dimuna, 2010).

\subsubsection{Clients' duties and responsibilities}

Client commitment in the appointment of competent professionals is the first step for realisation of the quality building and performance (McAleenan, 2010). Client is required under the law to appoint competent professionals: architects, engineers, quantity surveyors, and project managers that will bring in their technical experts into use that will lead to the appointment of competent contractors to 
carry out the intended building project in a safe manner. Client is also required to get approval from the town planning authority that conformed to all buildings standards in terms of designs criteria and Town Planning laws.

Investigations into many building failures or collapses have been linked to clients' lack of commitment both at the planning and construction phases. According to Akindoyeni (2002) the desirability of client commitment and involvement stems from the incessant of buildings collapse in our major urban cities that are associated with loss of lives, property damage and protracted litigation. Clients' roles and responsibilities to all stages of building delivering chain are of utmost important. Emphasizing the importance of clients' roles and responsibilities in terms of buildings quality and performance, Iyagba (2002) maintains that clients should demonstrate visible commitment through appointment of competent professionals, robust procurement methods, and prequalification of contractors. Failure by clients to discharge these onuses responsibilities at the early project planning could result in building failure or total collapse.

\subsubsection{Duties and responsibilities of the appointed consultants}

The quality of the building will be judged by the stability and durability of its structure (Oloke, 2010). It is the responsibility of an engineer to ensure stability and durability through design criteria. According to the British Standard (BS) 8110 , the aim of any design is to achieve a probability that the structure being designed will perform an acceptable standard during their intended life span. According to John (2009), the goal of engineers in building design is to ensure that the buildings are designed and constructed in a safe manner so that the loads are sustained and transmitted safely.

Health and Safety Executive (HSE, 2010) maintains that designers should recognise their important roles concerning human lives as demanded by their professional codes of conduct by exercising diligent and due care when designing. The ILO (2010) emphasises that those involved with the design and planning of building should demonstrate visible commitment and ethical behaviour in discharging their professional responsibilities particularly during the early projects planning stages. Research conducted in both developed and developing countries show that design-related aspects have both direct and indirect impact on building stability or failure (Iyagba, 2009).

However, stability of buildings could be a function of strength of materials. Thus, Quantity surveyors' position as cost expert can alleviate most of the materials quality related problems by advising clients, architects and engineers on the alternative uses of construction materials in terms of quality, costs and its performance. Quantity surveyor being one of the key project stakeholders in construction project delivering chain, and more importantly as a cost expert to clients and contractors can influence building materials quality and its performance.

Paucity of funds is one of the major factors contributing to contractors' poor quality of work on site. Inadequate allocation of financial resources to building project during the early project planning or at the tendering stage could contribute to use of sub-standard materials by contractors on site (Brauer, 2006). Arguably, when contractors compromise standards due to lack of funds, the resultant effect will be building failure or total collapse.

\subsubsection{The roles and responsibilities of Government towards building collapse in Nigeria}

The Town and Country Planning Laws of each state of the Federation set out a development and planning control in place. The precept of these laws is aimed at controlling development to safeguard the public health and safety with particular reference to buildings and other developments. Legislation according to Bassey (1994) is always necessary to ensure that certain national, social and health needs are maintained. The non-compliance of the regulations by the officers of Town Planning Authority in some states of the Federation is worrisome. There are instances where the officers collude with the client or his agent to commence work on the site without the development permit as prescribed by the law.

The contraventions of these regulations have continued unabated as reported in many parts of the country thereby resulting in building failures and disasters (Fadamiro, 2002).The Guardian 
Newspaper (2016) reported that greed and corruption are becoming increasingly more of Nigerian culture. The vices of corruptions affect our daily life.

Study conducted by Dimuna (2010) on incessant incident of building collapse in Nigeria identified the use of substandard materials, particularly by private clients as one of the major causes. There is a link between the quality of materials used on construction site and buildings collapses. Dimuna (2010) further contends that the use of substandard or inferior materials on construction site is attributed to high incidence of buildings collapses in our urban cities.

Unethical behaviour of building manufacturers and suppliers in Nigeria market has much to be desired. For instance, it has been discovered in Nigeria that manufacturer of steel rod, which is one of the common materials used in building construction, reduced the sizes of the steel rods from $12 \mathrm{~mm}$ diameter to $11 \mathrm{~mm}$ diameter in order to make profit (Guardian, 2016). This love of money over love of life is unethical and should be stopped. When materials are manufactured in accordance to acceptable standards, there is probability for reduction of buildings failure or collapse.

\subsubsection{Duties and responsibilities of contracting firms}

Contractors have duties and responsibilities under the common law to carry out building construction without causing harm to workers and the general public. This can be achieved through planning, organising, controlling and monitoring of the construction phases and coordinating activities of other contractors on site (Howarth and Watson, 2009). It is the commitment shown by the management of contracting company at all levels that determines how building process will be planned, organised, controlled, and monitored to ensure that quality is achieved. Hopkins (2008) and Markewichz (2009) maintain that achieving desired quality in building requires commitment and management skills. Similarly, Oloke (2010) argues that implementation of high quality building during construction is largely dependent upon commitment at all levels of management in an organisation.

The top management of contracting organisation has responsibility to develop standards and quality assurance of each element of the building process and share it among the departments. For instance, quality required for foundation, concrete mix, formwork, and standards of materials to be incorporated into work are determined by top management and shared as a core value in the organisation. It has been noted that positive behaviour of top leaders send messages to workers on value management places on quality.

Howarth and Watson (2009) stated that managers play a crucial role in promoting building quality on site. Studies comparing low and high failure incidence on structure have shown that on sites where managers show commitment in materials quality control and supervision, such buildings have better performance in terms of structural stability and durability (Dimuna, 2010). Hinze (2006) states that on a building site characterised with poor quality work are those with poor material quality control and absence of site supervision. Howarth and Watson (2009) assert that site managers, team leaders or supervisors play an important role in shaping workers understanding by communicating to them the company's work ethics. Management commitment and leadership skills demonstrated both at the top level and at the shop floor by any contracting organisation has impact on building quality and performance.

\subsection{Methodology}

To achieve the aim and objectives of this study, a mixed research method approach was adopted. The assumption underlying a mixed method to research represents the two extremes of data continuum (Flick, 2014). Research problems are better understood by employing both quantitative and qualitative methods in a complementary manner (Leedy and Ormrod, 2014). Supporting the adoption of mixed methods in research, Flick (2014) argues that the fundamental objective of a mixed method is to "attack a research problem with a compendium of methods that have no overlapping weakness, in addition to their complementary strengths". The current research involves human behaviour and therefore the mixed method was considered to be appropriate. 
The qualitative method entailed conducting interviews. Interviewees were chosen from among Engineers, Architects, Contractors, Town planning Officers in Lagos State Ministry of Environment, Building Materials Merchants. The criterion for interviewee selection included knowledge of the field - should have been in practice for over ten years. Fifty professionals within Lagos State were contacted to participate in the study. However, twenty participated in the study. The decision to proceed with the twenty participants for the interview was made based on the fact that they have expert opinions on the subject matter.

Qualitative data collection does not rely on the statistical strength of the sample but rather on the quality of information. A phenomenological study can be conducted with less than twenty participants (Flick, 2014). Questions for the interviews were prepared beforehand in order to guide the discussions. An interview is an interaction between two or more people meant to gain insight relative to the identified problems (Leedy \& Ormrod, 2014; Flick, 2014). The primary sources of the interview questions included literature review on causes of building failure or collapse (Fadamiro, 2002; Iyagba, 2009; Dimuna, 2010). In addition, the questions allowed participating professionals to discuss their expertise and competencies relative to building designs, supervisions and monitoring.

The discussions with each interviewee were audio recorded with the prior permission of the interviewee and transcribed. The researchers listened several times to the recorded opinions and suggestions and thereafter transcribed them. To enhance validity of the findings, the transcribed versions were sent to the participants/interviewees who indeed vouched that accurate versions of the discussions were obtained. The interview method of data collection assisted the researchers to have a well-represented sample devoid of bias and also to increase the validity and reliability of the collected data.

The quantitative data collection involved a distribution of questionnaires to engineers, architects, quantity surveyors, town planners, building merchants operating within Lagos State, Nigeria. The questionnaire consisted three sections. The first section dealt with demographic information. The "yes" and "no" type of responses were solicited in the first section. The other sections consisted of questions partnering to factors contributing to building collapses in Nigeria urban cities. Respondents were required to rate their responses on a five point Likert scale.

A total of 150 questionnaires were distributed to the targeted respondents. However, only 70 questionnaires were correctly completed, translating to a response rate of $47 \%$. The face-to-face method was chosen for questionnaire distribution in order to overcome problems of low response rate as most targeted participants were ever busy professionals.

\subsection{Results and Discussion}

Analysis of demographic data of the respondents from the quantitative data collection method showed that, $43.3 \%$ of the respondents were between the age of 23 and 34 years, 56.7\% were above the age of 35 . Findings also showed that $25.2 \%$ of the respondents had worked in the construction industry for more than five years while $74.8 \%$ had worked in the industry for more than ten years. In terms of qualifications, $45 \%$ of the respondents indicated that they possessed Master Degree in their chosen professions and $82.2 \%$ indicated that they are registered members of their various institutes. The respondents' profile gave confidence to the researchers to conclude that the respondents were mature and their responses could be relied on.

\subsection{Greed and engagement of quacks by building clients}

In Table 1 presents answers pertaining to extend the respondents perceived greed and engagement of quacks by building client as a contributing factor to building collapse. The findings show that $67.7 \%$ of the respondents agreed to the statement, $23.7 \%$ did not agree, while $9.2 \%$ were not sure. 
Table 1: Do you agree that greed and engagement of quacks by building client contribute to building collapse?

\begin{tabular}{|l|l|l|}
\hline & Frequency & Percent \\
\hline Yes & 57 & 81.4 \\
\hline No & 21 & 15.7 \\
\hline Not sure & 2 & 2.9 \\
\hline Total & 70 & 100 \\
\hline
\end{tabular}

Greed and engagement of quacks by building owners have been identified as one of the contributing factors to building collapses in our major urban cities. Greed may exist in form of converting a bungalow designed building into two-storey building without regard to structural stability of the building (Akindoyeni, 2002). In addition to save cost some private clients become the purchasing officers of all the building materials and thereby end up buying inferior and substandard materials (Iyagba, 2009).

In the interview sessions, a question was posed to participants to elicit their perceptions on the extent greed and engagement of quacks by building clients could contribute to building collapse.

Q1- As a stakeholder in the building industry with years of experience, do you agree that clients' greed and engagement of quacks can contribute to building collapse? Almost all the interviewees answered "yes". One of the interviewees went further and stated that:

"Some private clients are the architect, the builder, the surveyor, the procurement officer, and the supervising engineer"

The involvement of competent professionals in planning and designing of building is very critical to its structural stability, functionality and performance. The desirability of clients' involvement and commitment to building stability, quality and performance was noted by Iyagba (2009), when he stated that clients should demonstrate visible commitment through appointment of competent professionals, robust procurement methods and prequalification of contractors.

\subsection{Regular site visit/inspection by appointed consultants}

The issue of regular site visit/inspection was investigated. Table 2 indicated responses from the respondents on the issue of regular site visit/inspections. The findings show that $35.7 \%$ of the respondents agreed that they regularly visit building construction site under their supervision. On the other hand, $55.7 \%$ indicated that they do not regularly visit site and $8.6 \%$ said that they were not sure.

Table 2: As appointed consultants do you visit building construction site regularly?

\begin{tabular}{|l|l|l|}
\hline & Frequency & Percent \\
\hline Yes & 25 & 35.7 \\
\hline No & 39 & 55.7 \\
\hline Not sure & 6 & 8.6 \\
\hline Total & 70 & 100 \\
\hline
\end{tabular}

The need for stringent quality control in materials and workmanships on building construction site is very important. Regular site visits and inspections by appointed consultants is one of the factors that ensure or promote quality control in materials and standard of workmanship on sites. The neglect of quality control due to irregular site visits by consultant engineers have resulted in incorporation of low quality materials and poor workmanship on sites. In relation to the abovementioned topic, questions pertaining to how regular do you as appointed consultants visit site to ensure that your designs are being carried out.

Q2- As appointed consultants how regular do you visit building construction project under your supervision?

In response to these questions, one of the interviewees said: 
"Construction clients, particularly the private owners do not employ the services of professionals where they do, they do not pay the charged fees, as a result I do not visit site regularly".

These comments supported the questionnaire survey finding of Akindoyeni (2002) study that 95\% of building collapses in Nigeria major urban cities were owned by private individuals, as a result of their negligence in employing competent and professional engineers.

\subsection{Factors contributing to unethical behaviour of key stakeholder toward building collapse}

Table 3 indicates the respondents' rating of the extent to which each of the identified factors contributes to building collapses in Nigeria major urban cities. Table 3 shows in terms of percentage, the responses for each rating on a scale of 1 (minor) to 5 (major). It is notable that all the eight identified factors had the mean scores above the midpoint of 3.00, which, with an average MS of 3.44, indicated that the respondents viewed the identified statements as being contributing factors to building collapses in Nigeria major urban cities.

The findings indicate that the respondents perceived greed and engagement of quacks by building clients, lack of commitment by top management of contracting firms, bribery and corruption among Town planning officers, engagement of incompetent site supervisors, and greed and profiteering among building materials merchants. These factors were ranked highest on the list.

Table 3: Factors contributing to unethical behaviour of key stakeholder toward building collapse

\begin{tabular}{|c|c|c|c|c|c|c|c|c|}
\hline \multirow[t]{3}{*}{ Factor } & \multirow[t]{3}{*}{ Unsure } & \multicolumn{5}{|c|}{ Response (\%) } & \multirow[t]{3}{*}{ MS } & \multirow[t]{3}{*}{ Rank } \\
\hline & & \multicolumn{5}{|c|}{ Minor...................Major } & & \\
\hline & & 1 & 2 & 3 & 4 & 5 & & \\
\hline $\begin{array}{l}\text { Greed and engagement of quacks by building } \\
\text { clients }\end{array}$ & 4.2 & 6.3 & 11.9 & 25.2 & 29.4 & 23.1 & 3.51 & 1 \\
\hline $\begin{array}{l}\text { Lack of commitment by top management of } \\
\text { contracting firms }\end{array}$ & 9.1 & 4.9 & 9.8 & 27.9 & 27.9 & 20.3 & 3.49 & 2 \\
\hline $\begin{array}{l}\text { Bribery and corruption among Town planning } \\
\text { officers }\end{array}$ & 7.7 & 5.6 & 14.7 & 23.1 & 28.7 & 20.3 & 3.47 & 3 \\
\hline Engagement of incompetent site supervisors & 8.4 & 7.7 & 10.5 & 27.9 & 31.5 & 13.9 & 3.46 & 4 \\
\hline $\begin{array}{l}\text { Greed and profiteering among building } \\
\text { materials merchants }\end{array}$ & 6.3 & 5.6 & 11.9 & 40.6 & 12.7 & 13.9 & 3.44 & 5 \\
\hline $\begin{array}{l}\text { Absence of quality control on building } \\
\text { materials }\end{array}$ & 5.6 & 9.1 & 12.6 & 29.4 & 32.2 & 11.2 & 3.43 & 6 \\
\hline Use of inferior building materials & 7.0 & 9.9 & 16.9 & 26.1 & 24.7 & 15.5 & 3.42 & 7 \\
\hline Shortage of trained Town planning officer & 7.7 & 6.9 & 18.2 & 30.8 & 27.3 & 14.1 & 3.41 & 8 \\
\hline
\end{tabular}

Interviews conducted with the participants also corroborated the questionnaire survey results and literature.

One of the interviewees made the following comments:

"Greed and engagement of quacks by client, particularly the private clients in Nigerian construction environment is a major cause of building collapse in our urban cities"

Iyagba (2009) pointed out that instances have shown that clients, particularly private clients engaged the services of quacks and sometimes abandon the original approved plan due to greed. As state before, client is required under the law to appoint competent professionals that will bring in their technical expertise into use that will lead to the appointment of competent contractors to carry out the intended building project in a safe manner. In addition, the use of substandard building materials by private clients is another source of concern governments and individuals (Dimuna, 2010).

Q3- Do we have Construction Materials Regulation and Control Board in place that is equivalent to National Agency for Food Drug Administration and Control (NAFDAC) in Nigeria?

In response to this question, one of the interviewees answered with affirmative "we have". 
He went further to comment that: "The Construction Materials Regulation and Control Board of Nigeria (CMRCBN), is ineffective and bedevilled with lack of incompetent professional to carry out its aims and objectives". "That in the developed countries construction materials cannot be placed on the market without carrying out performance certification and warranty test". "The materials must undergo series of tests to determine its structural properties before it can be placed in the market"

Unethical behaviour in form of bribery and corruption prevalent in Nigerian society according to Guardian (2016) impose serious challenges to all facets of our social lives and economic development. For instance, when Government officers compromise with importers of building materials or Town planner officers compromise with clients, the resultant effect will be increases in numbers of buildings disasters in Nigeria urban cities. Bribery and corruption has become a part of our social life and it should be rooted out in order to reduce its vices in our society. This value for money as against value for human lives is highly unethical and unacceptable.

\subsection{Conclusion}

Buildings collapses in the Nigerian major urban cites continues to engender an excessive number of fatalities, injuries and property damage. It deserves collective responsibilities of key participants in building construction delivery chain, particularly during the early planning and design stage. The clients as the owner and financier should demonstrate commitment through the appointment of professionals who bring in their technical know-how in selecting and appointing competent contractors to carry out the intended building project in most efficient and safe manner. Findings from the survey and interviews protocol indicated that client, engineers, architects, quantity surveyors, town planner, building materials merchant and contractors have pivotal roles and responsibilities in achieving livable, quality and functional buildings.

The study therefore, recommends the followings:

- That the existing Construction Materials Regulation and Control Board of Nigeria (CMRCBN), should be made to be more effective and live up to its aims and objectives.

- There is also a need to license contractors and specialist contractors for easy identification and investigation in a case of collapsed buildings, it is through this that apportionment of liability to persons or entity can be attained.

- The staffs of CMRCBN should be empowered through training and retraining to discharge their responsibilities more effectively.

- At the Federal and State levels both senior, middle and site managers of Town Planner Officers should undergo leadership and interpersonal skills development training.

- The key stakeholders should demonstrate commitment and ethical behaviour in carrying out their professional duties.

\section{References}

Akindoyeni, A. (2002) Professionalism in building design and construction, In Ogunsemi, D.R ed. Building collapse: causes, prevention and remedies. The Nigerian Institute of building: Ondo State chapter, 1-13.

Bassey, N. (1994) The management of construction, Kraft Books limited, Ibadan.

Brauer, L.R. (2006) Safety and health for engineers, $2^{\text {nd }}$ ed. New Jersey: Wiley-Interscience

Dimuna, K.O. (2010) Incessant incident of building collapse in Nigeria: A challenge to stakeholders, Global Journal of Research in Engineering, Vol.10 (4)1, pp. 75-85.

Fadamiro, J.A (2002) Assessment of building regulations and standards and implications for building collapse in Nigeria. In Ogunsemi, D.R ed. Building collapse: causes, prevention and remedies. The Nigerian Institute of building, Ondo State chapter: 28-39.

Flick, U. (2014) An introduction to qualitative research, $5^{\text {th }}$ edition. London, Sage. 
Guardian (2016) The Guardian Newspaper. Available at: https://guardian.ng/

Health and safety Executive (HSE) (2010) Reducing error and influencing behaviour: HSG-48. UK.

Howarth, T. and Watson, P. (2009) Construction safety management. UK: Wiley-Blackwell.

Hopkins, P. (2008) The skills crisis in the pipeline sector of the oil and gas business. Journal of Pipeline Engineering, 7(3), pp. 147-172.

Hinze, J.W. (2006) Construction safety, New Jersey: Prentice- Hall Inc.

International Labour Organization (2010) ILO standard on occupational safety health: promoting safe and healthy working environment: Geneva, ILO.

Iyabga, R.A. (2009) The menace of sick buildings: A challenge to all for its prevention and treatment, EAS Print Concept Ventures, Lagos.

Iyagba, R.A. (2002) "Tribute to Abdullsalam Abukakar: Contemporary essay in National Development" The effect of political decisions on the construction industry.

John, I. (2009) Reading-OHS management in construction industry, occupational health and safety practitioner, Australia, Available at: www.worksafe.wa.gov.au/institute, Accessed on 18 October 2011.

Leedy, P.D. and Ormrod, J.E. (2014). Practical research: Planning and design, ${ }^{\text {th }}$ edition, Upper saddle River, New Jersey: Pearson.

Markewicz, D. (2009) OSHA compliance alone doesn't cut it: An integrated safety and health management is needed, Industrial safety and hygiene news, 43(7), pp. 20-32.

McAleenan, P. (2010) Assessing Safety issues in construction, In Mcaleenan C. \& Oloke, D eds. ICE manual of Health and safety in construction, London: Thomas Telford, pp. 101-110.

Oloke, D. (2010) Responsibility of key holders in construction design and management. In McAleenan, C. \& Oloke, D. eds. ICE Manual of health and safety in construction, London: Thomas Telford, 29-37. 